\title{
PENERAPAN MODEL PEMBELAJARAN KOOPERATIF TIPE NHT MATERI LARUTAN ELEKTROLIT DAN NON ELEKTROLIT MELATIHKAN KETERAMPILAN KOMUNIKASI
}

\section{IMPLEMENTATION OF COOPERATIVE LEARNING MODEL NHT TYPE IN ELECTROLITE AND NON ELECTROLITE SOLUTION TO TRAIN COMMUNICATION SKILLS}

\author{
Vira Kartini Puspitaning Suwandi dan *Muchlis \\ Jurusan Kimia FMIPA Universitas Negeri Surabaya \\ e-mail: muchlis@unesa.ac.id
}

\begin{abstract}
Abstrak
Penelitian ini bertujuan memaparkan keterlaksanaan model pembelajaran kooperatif tipe NHT, aktivitas peserta didik, dan keterampilan komunikasi peserta didik dengan materi larutan elektrolit dan non elektrolit di SMAN 1 Sidoarjo. Rancangan yang digunakan dalam penelitian yakni one shoot case study design. Didapatkan hasil berupa (1) Keterlaksanaan sintaks model kooperatif tipe NHT mendapatkan skor persentase rata-rata berturut-turut di pertemuan 1,2, dan 3 sebesar 3,60; 3,81; dan 3,875 yang berkategori sangat baik disetiap pertemuan dari nilai maksimum 4,00. (2) Peserta didik beraktivitas relevan yang berarti peserta didik berlatih keterampilan komunikasi dengan beraktivitas sesuai dengan sintaks NHT memiliki skor persentase waktu aktivitas berturut-turut di pertemuan 1, 2, dan 3 sebesar 95.93\%, 98.15\%, dan 99.34\% dari jumlah keseluruhan waktu pembelajaran. (3) Keterampilan komunikasi peserta didik meliputi kualitas dan kuantitas. Persentase skor kuantitas bertanya peserta didik memperoleh kriteria cukup berturut-turut di pertemuan 1, 2, dan 3 sebesar 8,33\%, 19,44\%, dan 41,67\% kuantitas berpendapat memperoleh kriteria cukup selama tiga pertemuan sebesar $36,11 \%, 41,67 \%$, dan $58,33 \%$. Persentase kualitas bertanya peserta didik yang memperoleh kriteria baik sekali berturut-turut di pertemuan 1, 2, dan 3 sebesar 8,33\%, 11,11\%, dan $19,44 \%$, persentase kualitas berpendapat peserta didik yang memperoleh kriteria baik sekali selama tiga pertemuan sebesar $22,22 \%, 27,78 \%$, dan $30,56 \%$.
\end{abstract}

Kata kunci: NHT, Keterampilan Komunikasi, Elektrolit dan Non Elektrolit.

\begin{abstract}
The following research aims to describe implementation of NHT type cooperative learning models, students activities, and students communication skills with the matery of electrolyte and non-electrolyte solution at SMAN 1 Sidoarjo. The design used in this research is one shoot case study design. Obtained results in the form of (1) The implementation of the syntax of the NHT type cooperative model gets the average consecutive percentage scores at meetings 1, 2, and 3 of 3.60; 3.81; and 3,875 with the criteria is very good in everymeetings of the maximum value is 4.00. (2) Students on relevant activities which means students practice communication skills with activities according to the NHT syntax have a score of the percentage of time in a row of activities in meetings 1, 2 and 3 of 95.93\%, 98.15\%, and 99.34\% of the total amount of learning time. (3) Students' communication skills include quality and quantity. The percentage of quantity scores asked students to obtain sufficient criteria in succession at meetings 1, 2, and 3 of $8.33 \%, 19.44 \%$, and $41.67 \%$ of the quantity of opinion obtained sufficient criteria for three meetings of $36.11 \%, 41.67 \%$ and $58.33 \%$. The percentage of the quality of asking students who obtained the criteria once in a row at meetings 1, 2, and 3 was $8.33 \%, 11.11 \%$, and 19.44\%, the percentage of the quality of opinion of students who obtained the criteria very well for three meetings of $22.22 \%, 27.78 \%$ and $30.56 \%$.
\end{abstract}

Key Word: NHT, Communication Skills, Electrolyte and Non-Electrolyte

\section{PENDAHULUAN}

Standar dari isi kurikulum 2013 ilmu kimia termasuk mata perlajaran yang diamanatkan, kimia pada kelompok pengetahuan matematika dan sains ialah merancang dan melakukan percobaan [1]. Mempelajari mengenai sebuah fenomena yang berkaitan dengan kehidupan sehari-hari sangat erat berkaitan dengan ilmu kimia. Kimia merupakan ilmu sains dengan berdasar pada eksperimen, pasti, juga praktik. Ilmu kimia tidak hanya menuntut peserta didik untuk menghafal konsep, teori ataupun rumus saja tetapi juga menuntut peserta 
didik memperoleh konsep, teori juga diterapkan pada kehidupan sehari-hari.

Berdasarkan hasil angket yang disebar di SMAN 1 Sidoarjo pada hari Rabu, 13 November 2019, sebanyak $86,11 \%$ peserta didik kelas X IPA 2 tertarik dengan pembelajaran kimia, namun sebanyak 13,89\% mengatakan bahwa pembelajaran kimia sulit untuk dipelajari. Hal ini didukung oleh hasil angket bahwa sebanyak 50\% peserta didik mengalami kesulitan dalam memahami pelajaran kimia karena banyak hafalan, sebanyak 27,78\% mengalami kesulitan karena pelajaran kimia banyak hitungan, dan 13,89\% menyatakan bahwa pelajaran kimia sulit karena tidak disertai praktikum.

Materi larutan elektrolit dan non elektrolit merupakan materi dalam kimia. Hasil dilakukannya pra-penelitian di SMAN 1 Sidoarjo pada hari Rabu, 13 November 2019. Pada kelas XI IPA 1 sebanyak 47,22\% menyatakan materi kimia yang sulit dipahami adalah materi larutan elekrolit dan non elektrolit. Angket sebanyak 33,33\% materi tersebut dianggap sulit karena banyak hafalan.

Peserta didik kelas XI IPA 1 sebanyak $41,67 \%$ dan peserta didik kelas X IPA 2 sebanyak $45,46 \%$ menyatakan metode pembelajaran yang banyak digunakan guru yaitu metode ceramah dengan berpusat pada guru, dan pembelajaran cenderung tidak aktif yang didukung dengan pengamatan peneliti pada pembelajaran di kelas $\mathrm{X}$ IPA 2. Pengamatan ini dilakukan secara langsung dilakukan dengan melihat dari banyaknya peserta didik yang bertanya maupun berpendapat selama proses pembelajaran berlangsung.

Peserta didik di kelas X IPA 2 mengisi angket yang hasilnya menyatakan sebanyak $84,85 \%$ peserta didik yang pasif bertanya maupun berpendapat ketika belajar secara berkelompok. Keaktifan peserta didik menunjukkan hal proses pembelajaran masih rendah dan lebih dodominasi guru ketika pembelajaran berlangsung. Angket yang dihasilkan mendukung bahwa peserta didik sebanyak $78,79 \%$ lebih senang ketika belajar berkelompok karena peserta didik dapat memperoleh ilmu pengetahuan, wawasan maupun pengalaman, dan ketika berkelompok dapat terjadinya suatu komunikasi yang baik antar peserta didik. Terdapat beberapa pertanyaan pada angket yang berbeda antara kedua kelas tersebut dikarenakan tujuan peneliti untuk mengetahui bagaimana perbedaan pada kelas yang telah dan yang belum diberikan materi tersebut dengan guru yang sama.

Pencapaian kompetensi pada materi ini adalah sifat larutan elektrolit dan non elektrolit dapat dianalisis dan daya hantar listriknya. Materi ini pula yang memiliki banyak karakteristik yakni konsep penerapan larutan elektrolit dan non elektrolit yaitu ketika menguji suatu larutan kemudian dapat membedakan beberapa sifat larutan elektrolit berdaya hantar kuat, lemah, dan non elektrolit.

Berdasarkan fakta tersebut materi kimia larutan elektrolit dan non elektrolit membutuhkan suatu keterampilan sehingga dapat membantu atau menunjang yaitu dengan menggunakan keterampilan komunikasi, tercapainya kompetensi didiukung dengan adanya sebuah keterampilan yang menunjang pemahaman konsep dengan baik agar terjalin suatu komunikasi aktif sehingga menunjang kegiatan belajar mengajar [2].

Komunikasi merupakan unsur terpenting untuk menentukan keberhasilan suatu pembelajaran yang dimana hal tersebut terdapat adanya suatu pemindahan (transfer) ilmu dari komunikator yaitu pendidik dan peserta didik sebagai komunikan [3]. Keterampilan komunikasi terdiri dari keterampilan berbicara, yang dimana keterampilan berbicara meliputi keterampilan mengajukan pertanyaan dan pendapat.

Keterampilan komunikasi sangat penting dan harus dilatihkan kepada peserta didik agar efisien ketika melakukan komunikasi dalam kelompok [4]. Model kooperatif merupakan model pembelajaran dengan teknik kelas yang efektif sehingga dapat digunakan guru untuk membantu peserta didik belajar, dimulai dengan keterampilan dasar hingga pemecahan suatu masalah kompleks. Peserta didik bekerja dengan diskusi kelompok kecil sehingga saling membantu belajar satu sama dengan lainnya, yang tentunya membuat mereka akan terus saling interaksi dan komunikasi. Setiap kelompok dibentuk secara heterogen dalam model kooperatif [5]. 
NHT (Number Head Together) merupakan golongan dari model pembelajaran kooperatif. Peserta didik dilatihkan keterampilan komunikasi oleh guru dengan menggunakan model NHT, dimana ketika proses belajar peserta didik dikondisikan agar saling bertanya dan berpendapat pada kegiatan tersebut, sehingga peserta didik dapat berkomunikasi dengan bertukar pengetahuan. Empat hal penting dalam Numbered Heads Together ialah a)Penomoran (Numbering), b)Pengajuan pertanyaan (Questioning), c)Berpikir bersama (Head Together), dan d)Pemberian Jawaban (Answering) [6].

NHT dapat menekankan pada aktivitas partisipasi peserta didik dalam proses pembelajaran khususnya ketika menjawab pertanyaan yang membuat peserta didik harus siap kapan saja untuk menjawabnya. Peserta didik berbagi pengetahuan sampai dapat menemukan solusi yang tepat. Model pembelajaran kooperatif tipe NHT ini mampu untuk memberikan kesempatan bagi peserta didik untuk berpikir lebih spesifik dan detail, dapat menyesuaikan setiap solusi yang diberikan oleh anggota kelompok, dapat memberi solusi sehingga dapat memecahkan suatu permasalahan, dan dapat membuat keputusan yang dapat dipertanggungjawabkan [7].

Penerapan pembelajaran kooperatif tipe NHT didukung oleh peran guru sebagai fasilitator yang mengelola kegiatan pembelajaran [8]. Terciptanya suasana belajar untuk mengaktifkan peserta didik saat proses belajar merupakan hal penting jika dapat dilakukan oleh guru [9].

Berdasarkan penjabaran tersebut, maka dilakukan Penerapan Model Pembelajaran Kooperatif Tipe NHT pada Materi Larutan Elektrolit dan Non Elektrolit untuk Melatihkan Keterampilan Komunikasi Peserta Didik Kelas X di SMA Negeri 1 Sidoarjo. Pengamatan keterlaksanaan penggunaan model pembelajaran berfungsi sebagai data penting peningkatan keterampilan komunikasi peserta didik yang merupakan hasil dari penelitian ini. Selain itu, untuk mengetahui bahwa aktivitas dari peserta didik telah relevan dengan sintaks model pembelajaran yang digunakan dan siswa telah berlatih komunikasi, maka perlu diamati aktivitas siswa saat pembelajaran berlangsung. Hasil akhir yang diinginkan pada penelitian ini yaitu untuk mendeskripsikan keterampilan komunikasi.

\section{METODE}

Rancangan yang digunakan yakni One Shoot Case Study yang digambarkan sebagai berikut:

$$
\mathbf{X} \rightarrow \mathbf{O}
$$

Keterangan:

$\mathrm{X}=$ Penerapan model kooperatif $N H T$ pada

materi larutan elektrolit dan non elektrolit.

$\mathrm{O}=$ Keterampilan komunikasi meliputi

keterampilan bertanya dan berpendapat siswa.

Subjek penelitian adalah peserta didik kelas X MIPA 2 SMAN 1 Sidoarjo yang berjumlah 36 orang dan pelaksanaan pada tahun ajaran 2019/2020 di semester genap memasuki materi larutan elektrolit dan non elektrolit. Guru menggunakan perangkat pembelajaran antara lain ialah silabus, RPP, dan LKPD. Instrumen yang digunakan antara lain lembar observasi keterlaksanaan model kooperatif NHT, lembar observasi aktivitas peserta didik, dan lembar penilaian keterampilan komunikasi.

Keterlaksanaan model kooperatif NHT berfungsi untuk mengamati kualitas keterlaksanaan pada kesesuaian proses belajar dengan semua sintaks kooperatif NHT. Terdapat dua orang observer yang mengamati keterlaksanaan pembelajaran menggunakan instrumen lembar observasi kemudian diperoleh keterlaksanaan pembelajaran yang relevan dengan indikator pengamatan. Skor kriteria penilaian keterlaksanaan sintaks kooperatif NHT dijabarkan pada Tabel 1.

Tabel 1. Skor Kriteria Penilaian Keterlaksanaan Model Pembelajaran

\begin{tabular}{cc}
\hline Skor & Keterangan \\
\hline 0 & Pembelajaran tidak terlaksana \\
1 & Terlaksana kriteria buruk \\
2 & Terlaksana kriteria cukup \\
3 & Terlaksana kriteria baik \\
4 & Terlaksana kriteria sangat baik \\
\hline
\end{tabular}


Pemberian skor pada penilaian keterlaksanaan model kooperatif NHT yang kemudian dianalisis menggunakan rumus berikut:

$$
\begin{aligned}
& \text { kualitas keterlaksanaan } \\
& =\frac{\sum \text { skor tiap langkah pembelajaran }}{\sum \text { skor keseluruhnya }}
\end{aligned}
$$

Skor yang diperoleh kemudian dikonversikan seperti Tabel 2.

Tabel 2. Kriteria Kualitas Keterlaksanaan Model Pembelajaran

\begin{tabular}{cc}
\hline Skor & Keterangan \\
\hline $3,1-4,0$ & Sangat Baik \\
$2,1-3,0$ & Baik \\
$1,1-2,0$ & Cukup \\
$0,0-1,0$ & Buruk \\
\hline
\end{tabular}

Aktivitas peserta didik dianalisis dengan cara mengamati setiap 3 menit sekali selama 135 menit oleh 6 pengamat dan data dari 6 pengamat tersebut akan dirata-rata. Instrumen lembar pengamatan aktivitas peserta didik digunakan untuk mengetahui hasil pengamatan terhadap aktivitas siswa yang akan diperoleh aktivitas yang relevan dengan indikator pengamatan. Data yang diperoleh dari observer yang selanjutnya dilakukan analisis perhitungan persentase kegiatan yang dilakukan peserta didik selama pembelajaran menggunakan model kooperatif NHT, dengan rumus sebagai berikut:

$$
\begin{aligned}
& \text { \%waktuAktivitas Siswa } \\
& =\frac{\sum \text { waktu aktivitas siswa }}{\sum \text { waktu aktivitas keseluruhan }} \times 100 \%
\end{aligned}
$$

Aktivitas peserta didik dinyatakan terlaksana baik dan menunjang untuk meningkatkan keterampilan komunikasi, apabila persentase aktivitas relevan lebih tinggi daripada aktivitas tidak relevan.

Data keterampilan komunikasi peserta didik diperoleh hasil pengamatan observer pada peserta didik selama proses KBM berlangsung. Lembar penilaian untuk mengamati keterampilan komunikasi siswa berfungsi sebagai penilaian analisis kualitas komunikasi dan kuantitas komunikasi peserta didik. Setiap pertemuan dilakukan analisis secara keseluruhan dengan menggunakan perhitungan berikut:

$\%$ Kuantitas komunikasi siswa $=\frac{\text { jumlah peserta didik yang berkomunikasi }}{\text { jumlah seluruh siswa }} \times 100 \%$

\%Kualitas komunikasi siswa $=\frac{\text { jumlah skor yang diperoleh }}{\text { jumlah skor seluruhnya }} \times 100 \%$

Data hasil pengamatan yang diperoleh dianalisis sesuai kriteria yang dijabarkan pada Tabel 3.

Tabel 3. Kriteria Penilaian Keterampilan Komunikasi

\begin{tabular}{ccc}
\hline No. & $\begin{array}{c}\text { Perserntase } \\
\text { Gain score } \\
(\boldsymbol{\%})\end{array}$ & Kriteria \\
\hline 1 & $0-20$ & Sangat buruk \\
2 & $21-40$ & Buruk \\
3 & $41-60$ & Cukup \\
4 & $61-80$ & Baik \\
5 & $81-100$ & Sangat baik \\
\hline
\end{tabular}

Keterampilan komunikasi peserta didik dikatakan baik jika mencapai predikat baik dengan persentase $\geq 61 \%$ jika berdasar pada tabel tersebut.

\section{HASIL DAN PEMBAHASAN}

\section{Keterlaksanaan Model Pembelajaran Inkuiri Terbimbing}

Pelaksanaan pembelajaran kooperatif, guru membutuhkan partisipasi dan kerja sama dalam kelompok belajar [11]. Model pembelajaran yang inovatif dalam pembelajaran ilmu sosial bertujuan untuk meringankan beban peserta didik dalam menguasai materi dan cakupan luas [12].

NHT adalah pembelajaran yang lebih berfokus pada kemampuan belajar peserta didik untuk membangun konsep untuk diri mereka sendiri [13]. Keterlaksanaan model ini dilaksanakan guru dalam hal ini yaitu peneliti dan pelaksanaannya disesuaikan dengan RPP. Keterlaksanaan model pembelajaran ini memperoleh hasil pengamatan dari 2 orang pengamat yang merupakan mahasiswa jurusan pendidikan kimia Unesa menggunakan instrumen lembar pengamatan keterlaksanaan sintaks NHT. 
Sintaks pembelajaran dari kooperatif sendiri terdapat 6 fase yakni 1) Menjelaskan tujuan dan membuka pembelajaran, 2) menyajikan informasi, 3) mengatur peserta didik dalam tim belajar, 4) membatu kerja tim dan belajar, 5) evaluasi, dan 6) memberikan penghargaan [5].

Diagram pengamatan keterlaksanaan model ini terdapat dalam Gambar 1.

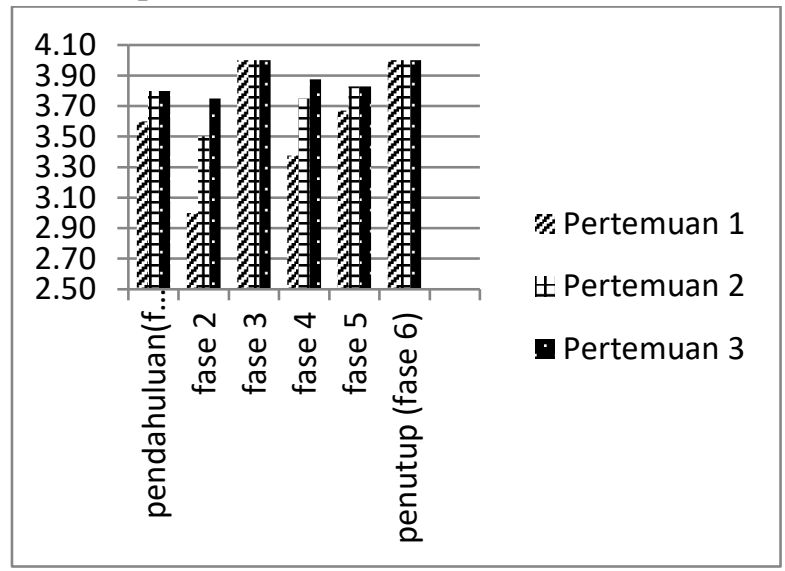

Gambar 1. Diagram Keterlaksanaan Model Pembelajaran Kooperatif Tipe NHT

Gambar 1 menjelaskan jika dirata-rata, skor keterlaksanaan sintaks NHT secara berturut- turut di pertemuan 1, 2, dan 3 sebesar 3,60; 3,81; dan 3,875 dimana ketiganya berkriteria sangat baik. Keterlaksanaan pembelajaran dapat dikatakan baik jika nilai kualitas keterlaksanaan $\geq 2,1$ yaitu pada kategori baik atau sangat baik. Sintaks dari model pembelajaran menghasilkan skor yang dapat menunjukkan bahwa guru mampu menerapkan sintaks model pembelajaran kooperatif tipe NHT dengan baik.

\section{Aktivitas Peserta Didik}

Aktivitas peserta didik yang diamati berfungsi sebagai pengamatan kesesuaian seluruh aktivitas peserta didik selama proses pembelajaran berlangsung dengan sintaks NHT dan untuk mengamati keterampilan komunikasi peserta didik telah dilatihkan yang meliputi keterampilan komunikasi bertanya dan berpendapat.

Hasil pengamatan aktivitas ini diperoleh melalui instrumen lembar pengamatan aktivitas peserta didik yang dinilai oleh sebanyak 6 orang pengamat yang terdiri dari mahasiswa Jurusan Pendidikan Kimia Unesa. Setiap pengamat mengamati 1 kelompok kecil beranggotakan 6 peserta didik dan satu kelas terdiri dari 6 kelompok. Pengamat harus mengamati aktivitas peserta didik yang secara dominan muncul setiap 3 menit sekali selama 135 menit pada proses pembelajaran. Hasil rekapitulasi pengamatan aktivitas peserta didik selama tiga kali pertemuan dapat dilihat pada Tabel 4.

Tabel 4. Rekapitulasi Pengamaan Aktivitas

\begin{tabular}{|c|c|c|c|}
\hline \multirow{2}{*}{ Aktivitas Peserta Didik } & \multicolumn{3}{|c|}{ Persentase (\%) } \\
\hline & P 1 & $\mathbf{P} 2$ & P 3 \\
\hline $\begin{array}{l}\text { Peserta didik mendengarkan } \\
\text { dan memperhatikan penjelasan } \\
\text { guru }\end{array}$ & 21.11 & 15.93 & 13.79 \\
\hline $\begin{array}{l}\text { Peserta didik mendiskusikan } \\
\text { jawaban soal yang terdapat } \\
\text { pada LKPD secara } \\
\text { berkelompok }\end{array}$ & 16.67 & 15.93 & 13.79 \\
\hline $\begin{array}{l}\text { Peserta didik } \\
\text { mempresentasikan hasil belajar } \\
\text { kelompoknya }\end{array}$ & 11.85 & 14.07 & 14.44 \\
\hline $\begin{array}{l}\text { Peserta didik mengajukan } \\
\text { pertanyaan pada guru maupun } \\
\text { pada kelompok yang presentasi }\end{array}$ & 15.19 & 17.41 & 18.89 \\
\hline $\begin{array}{l}\text { Peserta didik menyanggah atau } \\
\text { memberikan pendapat pada } \\
\text { kelompok yang sedang } \\
\text { presentasi }\end{array}$ & 17.78 & 20.37 & 21.11 \\
\hline $\begin{array}{l}\text { Peserta didik menyimpulkan } \\
\text { materi pembelajaran }\end{array}$ & 13,33 & 14.44 & 14.07 \\
\hline Jumlah aktivitas yang relevan & 95.93 & 98.15 & 99.34 \\
\hline $\begin{array}{l}\text { Peserta didik melakukan } \\
\text { aktivitas yang tidak relevan } \\
\text { (seperti bermain handphone, } \\
\text { bergurau, tidur, dsb) }\end{array}$ & 4.07 & 1,85 & 0,74 \\
\hline Jumlah Aktivitas Keseluruhan & 100 & 100 & 100 \\
\hline
\end{tabular}

Berdasarkan deskripsi-deskripsi aktivitas peserta didik bahwa peserta didik melakukan aktivitas relevan dalam arti peserta didik telah berlatih keterampilan komunikasi dan beraktivitas sesuai dengan sintaks NHT pada materi larutan elektrolit dan non elektrolit secara berturut-turut persentasenya di pertemuan 1, 2, dan 3 sebesar 95,93\%; 98,15\%; dan 99,34\%. Persentase tersebut menunjukkan bahwa aktivitas peserta didik dikatakan mendukung keefektifan penerapan NHT untuk melatihkan keterampilan komunikasi kepada peserta didik karena persentase aktivitas relevan lebih tinggi dibandingkan dengan persentase aktivitas peserta didik yang tidak relevan.

Hubungan aktivitas peserta didik dengan keterampilan komunikasi yaitu persentase aktivitas yang relevan lebih tinggi daripada persentase aktivitas yang tidak relevan. Keterkaitan aktivitas 
dengan keterampilan komunikasi disajikan pada

Gambar 2.

\section{Aktivitas Peserta Didik}

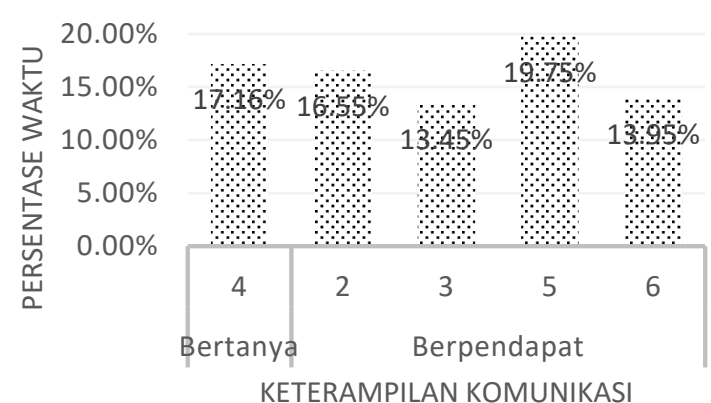

Gambar 2. Diagram Hubungan Aktivitas Peserta Didik dengan Keterampilan Komunikasi Peserta Didik

Berdasarkan diagram pada Gambar 2 menandakan bahwa peserta didik menggunakan waktunya pada ketiga pertemuan untuk persentase rata-rata berlatih keterampilan komunikasi bertanya sebesar $17,16 \%$ sedangkan persentase rata-rata keterampilan berpendapat peserta didik menggunakan waktunya berjumlah total sebesar $63,70 \%$. Berdasarkan uraian tersebut aktivitas peserta didik memiliki peranan penting dalam mendukung keefektifan dan terlaksananya sintaks NHT oleh guru.

\section{Keterampilan Komunikasi}

Menerapkan model pembelajaran kooperatif peserta didik dapat dimungkinkan untuk mencapai keberhasilan dalam belajar, seperti melatihkan keterampilan sosial untuk mengekspresikan pendapat, menerima saran, bekerja sama, solidaritas, dan mengurangi perilaku yang menyimpang [14].

Komunikasi terdiri atas mendengar, bicara, dan non verbal. Komunikasi dengan berbicara antara lain berpendapat dan mengajukan pertanyaan [15]. Keterampilan komunikasi merupakan satu dari beberapa keterampilan guru yang wajib dikuasi saat mengajar, namun untuk membuat pembelajaran jadi lebih aktif, keterampilan komunikasi wajib dimiliki peserta didik [16].

Keterampilan komunikasi hanya dapat didapatkan dan dikuasai dengan jalan praktek dan latihan [17]. Keterampilan komunikasi yang dilatihkan dengan menggunakan kooperatif NHT pada materi larutan elektrolit dan non elektrolit dilakukan selama 3 kali pertemuan proses pembelajaran. Peserta didik dilatihkan keterampilan komunikasi yang meliputi kuantitas dan kualitas dari keterampilan bertanya dan berpendapat.

Sintaks NHT yang sesuai dengan kebutuhan untuk melatihkan keterampilan komunikasi peserta didik sehingga pembelajaran dapat menjadi lebih aktif, menarik, dan bermakna [5]. Keterampilan komunikasi bertanya dan berpendapat ini dimulai ketika sintaks model pembelajaran kooperatif tipe NHT ini berada pada fase 4 Membimbing kelompok bekerja dan belajar di tahapan Berpikir bersama (head together) dan pada fase 5 yakni evaluasi.

a. Kuantitas Bertanya dan Berpendapat

Kuantitas bertanya dan berpendapat ini diamati dari jumlah banyaknya peserta didik yang bertanya maupun berpendapat, bukan dari jumlah pertanyaan atau pendapat yang dikemukakan oleh peserta didik. Data kuantitatif keterampilan komunikasi bertanya maupun berpendapat peserta didik selama tiga pertemuan dijabarkan dalam diagram kuantitas komunikasi, terdapat pada Gambar 3.

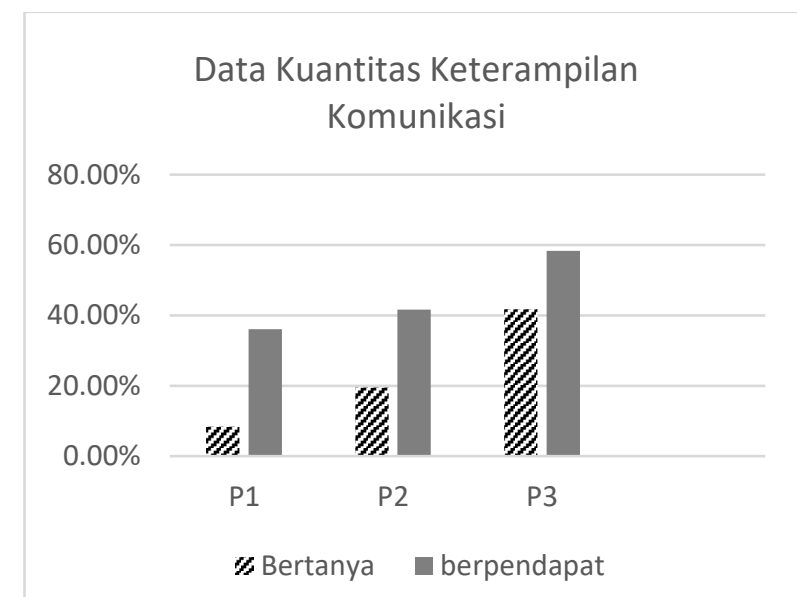

Gambar 3. Diagram Data Kuantitas Komunikasi Bertanya dan Berpendapat

Persentase skor kuantitas keterampilan komunikasi bertanya dan berpendapat pada setiap pertemuan yang berarti peserta didik mengalami kemajuan untuk keterampilan komunikasinya baik bertanya maupun berpendapat. Selama tiga 
pertemuan masih terdapat beberapa peserta didik yang tidak pernah bertanya maupun berpendapat, hal ini dikarenakan kemampuan menanya merupakan wujud sikap kritis peserta didik atas materi dan pembelajaran yang dilakukannya [18].

Alasan mengapa peserta didik jarang yang mengajukan pertanyaan daripada berpendapat dikarenakan kurangnya sikap kritis peserta didik [19]. Keterampilan komunikasi melalui berpendapat dan bertanya antara peserta didik dapat membina daya nalar. Sesuai dengan teori tersebut maka keterampilan komunikasi perlu dilatihkan dengan waktu yang lebih lama dan lebih memperhatikan kemampuan peserta didik.

Berdasarkan gambar 3 di atas kuantitas komunikasi peserta didik berkategorikan cukup baik selama tiga pertemuan, sehingga disimpulkan bahwa penerapan model pembelajaran kooperatif tipe NHT dapat mendukung dilatihkannya keterampilan komunikasi peserta didik baik bertanya maupun berpendapat.

b. Kualitas Bertanya Peserta Didik

Kualitas bertanya peserta didik ini diamati dengan menganalisis setiap pertanyaan yang dikemukakan oleh peserta didik yang digolongkan dalam tingkatan Taksonomi Bloom yaitu C1 - C4 yang dilatihkan, pengamatan kualitas keterampilan bertanya peserta didik diamati dengan menggunakan instrumen kualitas keterampilan bertanya peserta didik.

Pertemuan pertama terdapat sebanyak 8,33\% persentase dari jumlah keseluruhan peserta didik mengajukan pertanyaan dengan kategori baik sekali. Pertemuan kedua terdapat sebanyak 8,33\% dari persentase jumlah total peserta didik mengajukan pertanyaan dengan kategori kurang dan sebanyak $11,11 \%$ dari persentase jumlah total peserta didik mengajukan pertanyaan dengan kategori baik sekali. Pada pertemuan ketiga terdapat sebanyak 22,22\% dari persentase jumlah total peserta didik mengajukan pertanyaan dengan kategori kurang dan sebanyak 19,44\% dari persentase jumlah total peserta didik mengajukan pertanyaan dengan kategori baik sekali. Berikut merupakan data kualitas bertanya peserta didik yang disajikan pada Gambar 4.

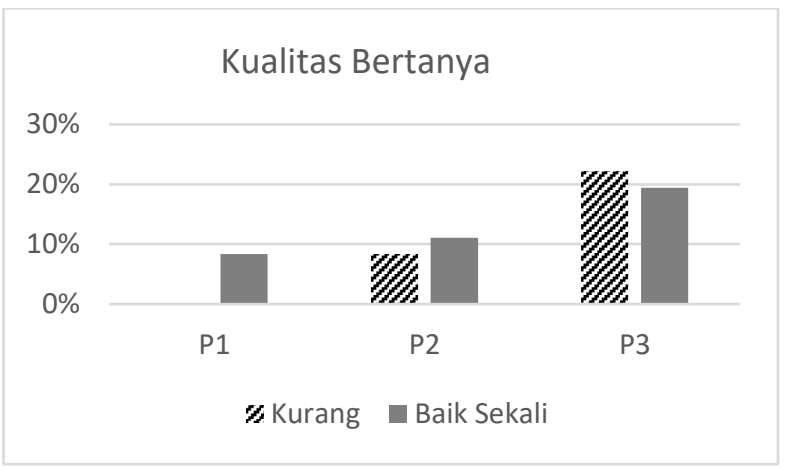

Gambar 4. Diagram Data Kualitas Bertanya

Data kualitas bertanya peserta didik dipertemuan 1, 2, dan 3 mengalami adanya peningkatan serta pencapaian kualitas bertanya peserta didik sesuai dengan yang dilatihkan yakni tingkatan Taksonomi Bloom C1 - C4. Data diatas menunjukkan kualitas keterampilan komunikasi bertanya oleh peserta didik berkategori cukup baik mengalami peningkatan disetiap pertemuannya.

c. Kualitas Berpendapat Peserta Didik

Kualitas keterampilan komunikasi berpendapat peserta didik ini diamati berdasarkan logis dan analitisnya pendapat yang dikemukakan oleh peserta didik. Logis yaitu penyampaian pendapat yang didasarkan fakta dan kenyataan adanya untuk mendukung pendapat yang disampaikan. Analitis apabil pendapat tersebut disampaikan dengan kata yang jelas, baik, dan mudah dimengerti pendengarnya.

Pertemuan 1 sebanyak $13,89 \%$ dari persentase jumlah total peserta didik mengajukan pendapat dengan kategori baik dan sebanyak $22,22 \%$ dari persentase jumlah total peserta didik mengajukan pendapat dengan kategori baik sekali. Pertemuan 2 sebanyak 2,78\% dari persentase jumlah total peserta didik mengajukan pendapat dengan kategori cukup, $27,78 \%$ dari persentase jumlah total peserta didik mengajukan pendapat dengan kategori baik dan sebanyak $27,78 \%$ dari persentase jumlah total peserta didik mengajukan pendapat dengan kategori baik sekali. Pertemuan 3 sebanyak $2,78 \%$ dari persentase jumlah total peserta didik mengajukan pendapat dengan kategori cukup, $27,78 \%$ dari persentase jumlah total peserta didik mengajukan pendapat dengan kategori baik dan sebanyak 30,56\% dari persentase jumlah total peserta didik mengajukan pendapat dengan kategori baik sekali. Berikut 
merupakan data kualitas berpendapat peserta didik yang digambarkan pada Gambar 5.

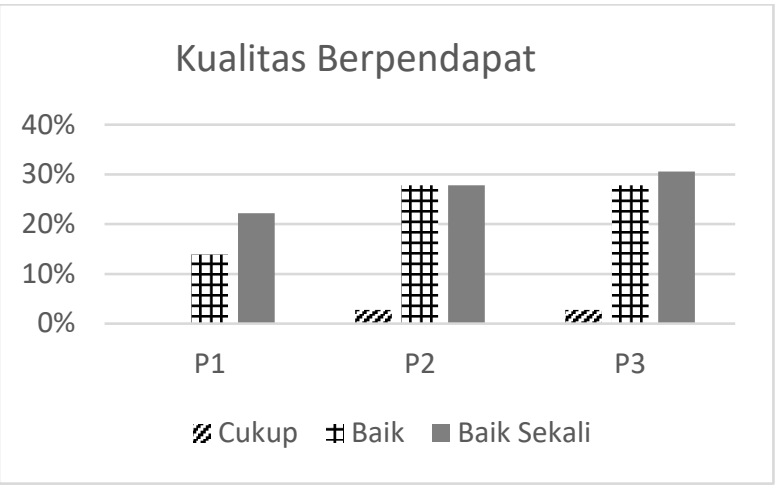

Gambar 5. Diagram Data Kualitas Berpendapat

Data yang terdapat pada Gambar 5 mendeskripsikan adanya peningkatan kualitas berpendapat yang dialami peserta didik di pertemuan 1, 2, dan 3 mengalami peningkatan berkriteria baik sekali dengan pencapaian pendapat yang dikemukakan peserta didik ini logis dan analitis, sehingga menunjang kebenaran pendapat peserta didik sesuai dengan ilmu yang ada.

Pada setiap pertemuan peserta didik dibagi dalam beberapa kelompok untuk menunjang kemampuan komunikasinya, yang mana pada proses ini terjadi kemungkinan peserta didik untuk saling berinteraksi antara satu sama dengan lainnya untuk bertukar wawasan, bertanggung jawab unruk menyelesaikan tugas, dan menghasilkan percaya diri dalam mengekspresikan pendapat [20].

\section{Hasil Belajar sebagai Data Pendukung}

Hasil belajar didapatkan dari perolehan nilai posttest yang dikerjakan setiap peserta didik secara individu pada akhir pertemuan 3. Diadakannya kegiatan posttest berfungsi untuk mengamati dan menilai kemampuan kognitif peserta didik setelah diterapkannya NHT dengan materi larutan elektrolit dan non elektrolit. Posttest berisikan sebanyak 10 soal pilihan ganda dengan menggunakan tingkatan kognitif yang berbeda dari $\mathrm{C} 1$ hingga $\mathrm{C} 4$ sesuai dengan yang telah dilatihkan oleh guru pada peserta didik selama proses pembelajaran berlangsung. Berikut hasil dari posttest yang telah diperoleh disajikan pada Tabel 5
Tabel 5. Nilai Posttest Peserta Didik

\begin{tabular}{|c|c|c|c|}
\hline No. & Nama & Nilai Posttest & Keterangan \\
\hline 1. & ADB & 100 & $\mathrm{~T}$ \\
\hline 2. & $\mathrm{AR}$ & 100 & $\mathrm{~T}$ \\
\hline 3. & AEA & 90 & $\mathrm{~T}$ \\
\hline 4. & BW & 100 & $\mathrm{~T}$ \\
\hline 5. & CRDA & 100 & $\mathrm{~T}$ \\
\hline 6. & DAP & 90 & $\mathrm{~T}$ \\
\hline 7. & DR & 100 & $\mathrm{~T}$ \\
\hline 8. & DAA & 90 & $\mathrm{~T}$ \\
\hline 9. & DAAA & 100 & $\mathrm{~T}$ \\
\hline 10. & DNK & 100 & $\mathrm{~T}$ \\
\hline 11. & $\mathrm{EC}$ & 100 & $\mathrm{~T}$ \\
\hline 12. & FKA & 100 & $\mathrm{~T}$ \\
\hline 13. & FFD & 100 & $\mathrm{~T}$ \\
\hline 14. & FAN & 100 & $\mathrm{~T}$ \\
\hline 15. & HSR & 100 & $\mathrm{~T}$ \\
\hline 16. & HIF & 100 & $\mathrm{~T}$ \\
\hline 17. & IMMYAK & 100 & $\mathrm{~T}$ \\
\hline 18. & IWBA & 100 & $\mathrm{~T}$ \\
\hline 19. & KAN & 100 & $\mathrm{~T}$ \\
\hline 20. & MAAP & 90 & $\mathrm{~T}$ \\
\hline 21. & MRM & 100 & $\mathrm{~T}$ \\
\hline 22. & MRR & 90 & $\mathrm{~T}$ \\
\hline 23. & MR & 90 & $\mathrm{~T}$ \\
\hline 24. & NPS & 100 & $\mathrm{~T}$ \\
\hline 25. & NS & 100 & $\mathrm{~T}$ \\
\hline 26. & NIHS & 90 & $\mathrm{~T}$ \\
\hline 27. & NADK & 100 & $\mathrm{~T}$ \\
\hline 28. & RDF & 100 & $\mathrm{~T}$ \\
\hline 29. & SAP & 100 & $\mathrm{~T}$ \\
\hline 30. & SM & 80 & $\mathrm{~T}$ \\
\hline 31. & TGT & 100 & $\mathrm{~T}$ \\
\hline 32. & VNF & 100 & $\mathrm{~T}$ \\
\hline 33. & VJE & 100 & $\mathrm{~T}$ \\
\hline 34. & WKA & 100 & $\mathrm{~T}$ \\
\hline 35. & YIAM & 100 & $\mathrm{~T}$ \\
\hline 36. & YYF & 90 & $\mathrm{~T}$ \\
\hline \multicolumn{3}{|c|}{ Ketuntasan Klasikal } & $100 \%$ \\
\hline
\end{tabular}

Berdasarkan nilai data hasil pembelajaran (Posttest) peserta didik disajikan di Tabel 5 diatas memperlihatkan bahwa seluruh peserta didik kelas X MIPA 2 dinyatakan tuntas selama dilatihkannya keterampilan komunikasi dengan menggunakan NHT, ketuntasan klasikal pada posttest peserta didik ialah sebesar $100 \%$ dengan rata-rata posttest 97,22 . Nilai tersebut menunjukkan bahwa sebanyak $100 \%$ peserta didik mendapatkan nilai diatas 75 sehingga penerapan kooperatif NHT pada materi larutan elektrolit dan non elektrolit dikatakan tuntas.

\section{SIMPULAN}

1. Hasil keterlaksanaan dari sintaks penerapan model Numbered Head Together (NHT) pada materi larutan elektrolit dan non elektrolit 
untuk melatihkan keterampilan komunikasi peserta didik kelas $\mathrm{X}$ di SMAN 1 Sidoarjo selama dilakukannya 3 kali pertemuan mengalami peningkatan persentase rataratanya. Persentase rata-rata secara berturutturut di pertemuan 1, 2 dan 3 sebesar 3,60, $3,81,3,875$ dengan kategori sangat baik disetiap pertemuannya.

2. Aktivitas peserta didik selama proses pembelajaran berlangsung telah mencerminkan model Numbered Head Together (NHT) dalam melatihkan keterampilan komunikasi, skor persentase aktivitas peserta didik yang relevan lebih besar dibandingkan dengan aktivitas peserta didik yang tidak relevan. Aktivitas peserta didik yang relevan secara berturut-turut di pertemuan 1, 2 dan 3 sebesar 95,93\%, 98,15\%, dan $99,34 \%$ dari jumlah total waktu keseluruhan pembelajaran.

3. Keterampilan komunikasi peserta didik meliputi kuantitas dan kualitas bertanya dan berpendapat yang diolah menjadi bentuk data dalam persentase. Persentase kuantitas bertanya peserta didik secara berturut-turut di pertemuan 1, 2 dan 3 sebesar 8,33\%, $19,44 \%$,dan $41,67 \%$ hasil yang didapatkan memperoleh predikat cukup dan keterampilan komunikasi kuantitas bertanya dalam proses pembelajaran selama 3 pertemuan mengalami peningkatan, sedangkan kuantitas berpendapat peserta didik secara berturut-turut di pertemuan 1, 2 dan 3 sebesar $36,11 \%, 41,67 \%$, dan $58,33 \%$ hasil yang didapatkan memperoleh predikat cukup dan keterampilan komunikasi kuantitas berpendapat dalam proses pembelajaran selama 3 pertemuan mengalami peningkatan. Persentase kualitas bertanya peserta didik yang memperoleh predikat baik sekali secara berturut-turut di pertemuan 1, 2 dan 3 sebesar 8,33\%, 11,11\%, dan $19,44 \%$ hasil yang didapatkan dari keterampilan komunikasi kualitas bertanya dalam proses pembelajaran selama 3 pertemuan mengalami peningkatan. Persentase kualitas berpendapat peserta didik yang memperoleh predikat baik sekali secara berturut-turut di pertemuan 1, 2 dan 3 sebesar $22,22 \%, 27,78 \%$, dan $30,56 \%$ hasil yang didapatkan memperoleh predikat cukup dan keterampilan komunikasi kuantitas berpendapat dalam proses pembelajaran selama 3 pertemuan mengalami peningkatan. Berdasarkan hasil diatas diperoleh bahwa telah mencerminkan proses KBM dengan menggunakan model NHT untuk melatihkan keterampilan komunikasi.

\section{SARAN}

1. Pada penilitian ini peserta didik dilatihkan keterampilan komunikasi (bertanya) hanya sampai pada tingkatan Taksonomi Bloom C1C4. Dengan adanya penelitian tersebut, diharapkan peneliti yang akan melakukan penelitian ini untuk lebih lanjut dalam meneliti yaitu dengan melatihkan keterampilan komunikasi untuk kualitas bertanya peserta didik ditingkatkan hingga tingkatan Taksonomi Bloom C6.

2. Dalam kegiatan pembelajaran guru dan pengamat megalami beberapa kendala dalam melakukan proses pembelajaran sehingga diharapkan untuk penelitian selanjutnya agar dapat memanajemen waktu dengan sebaikbaiknya.

3. Perlu dilakukannya penelitian lebih lanjut mengenai penelitian dengan menggunakan model NHT untuk dilatihkannya keterampilan komunikasi terhadap peserta didik di materi kimia yang lainnya agar dapat mengetahui dan mengukur keefektifan untuk penerapan model NHT untuk melatihkan keterampilan komunikasi peserta didik dalam pembelajaran lainnya.

\section{DAFTAR PUSTAKA}

1. Depdiknas. 2013. Peraturan Menteri Pendidikan Dan Kebudayaan Nomor 69 Tahun 2013 Tentang Kerangka Dasar Dan Struktur Kurikulum Sekolah Menengah Atas/Madrasah Aliyah. Jakarta: Badan Standar Nasional Pendidikan.

2. Fadhilah, A. F., \& Muchlis. 2016. Penerapan Model Pembelajaran Kooperatif Tipe Two 
Stay Two Stray Pada Materi Larutan Elektrolit dan Non elektrolit Untuk Melatihkan Keterampilan Komunikasi Siswa Kelas X SMA Negeri 2 Lamongan. Unesa Journal of Chemical Education, vol 5, No. 2, pp. 474 483.

3. Rosyada, D. 2004. Paradigma Pendidikan Demokratis. Jakarta: Prenada Media.

4. Nur, M. 2011. Model Pembelajaran Kooperatif Edisi Kedua Cetakan Kedua. Surabaya: Pusat Sains dan Matematika Sekolah Unesa.

5. Arends, R. I. 2013. Belajar untuk Mengajar. Edisi 9 buku 2. Jakarta: Salemba Humanika.

6. Leasa, M., \& Corebima, A, D. 2017. The Effect of Numbered Heads Together (NHT) Cooperative Learning Model on the Cognitive Achievement of Student with Different Academic Ability. Journal of Physics: Conference Series, 795(1), 012071.

7. Riduwan. 2015. Skala Pengukuran VariabelVariabel Penelitian. Bandung: Alfabeta.

8. Maman, Mayong, Andi A. R. 2016. The Implementation of Cooperative Learning Model 'Number Head Together (NHT)' in Improving the Students' Ability in Reading Comprehesion. International Journal of Evaluation and Research in Education, vol. 5, pp. 174-180.

9. Bruhn, A., Shanna H., \& Kari V. 2016. 'Motivating Instruction? There's an App for That!'. Interview. Sch. Clin., pp. 1053451216644825 .

10. Arifin. 2011. Metode Penelitian Kualitatif, Kuantitatif, dan $R \& D$. Bandung: Alfabeta.

11. Trisnawati, T., R. Pratiwi, \& Waziana. 2018. The Effect of Realistics Mathematics Education on Students' Mathematical Communication Ability. Malikussaleh Journal of Mathematics Learning (MJML), Vol. 1, No. 1, Hal. 31-35.
12. Eysink, T. 2016. Supporting Primary School Teachers in Differentiatig in the Regular Classroom. Teaching and Teacher Education, 66, 107-116.

13. Mursalin, M., Nuraina N., Rohantizani R., Fonna M., Muhammad I., Nufus H., Muliana M., Nuraini N. L. S., Purnomo H., Damayanti N.W., Wulandari Y. O., Mayangsari S. N., Kristanti D., Rohim A., Widyastuti R., Saleh H Sulastri R., \& Amalia R. 2018. The Development of Algebra Teaching Materials to Foster Student' Creative Thinking Skills in Higher Education. Journal of Physics: Conference Series Vol. 1088, No. 1, p. 012101. IOP Publishing.

14. Afandi, A. 2018. Difference of Learning Mathematics Between Open Question Model and Conventional Model. Malikussaleh Journal of Mathematics Learning (MJML), Vol. 1, No. 1, Hal. 13-18.

15. Santrock, J.W. 2011. Psikologi Pendidikan. Jakarta: Prenada Media Group.

16. Kurniawan R., \& Harun N. 2018. Melatihkan Keterampilan Komunikasi Peserta Didik Melalui Penerapan Model Pembelajaran Inkuiri Terbimbing pada Materi Laju Reaksi. Unesa Journal of Chemical Education, vol. 7, No. 1.

17. Tarigan, H. G. 1981. Berbicara sebagai Suatu Keterampilan Berbahasa. Bandung: Angkasa.

18. Kosasih. 2014. Strategi Belajar dan Pembelajaran. Bandung: Penerbit Yrama Widya.

19. Effendi, O. U. 2000. Dinamika Komunikasi. Bandung: PT. Remaja Rosdakarya.

20. Widyaningtyas, Harini, Retno W., \& Tri M. 2018. Developing Stidents' Responsibility Through Numbered Head Together Model in Social Science Learning at Elementary School. International Journal of Indonesian Education and Teaching, Vol. 2, No. 2. 